\title{
Observations on the reproductive and larval biology of Blennius pavo (Pisces: Teleostei)
}

\author{
H. v. Westernhagen \\ Biologische Anstalt Helgoland (Zentrale); Notkestraße 31, \\ 2000 Hamburg 52, Federal Republic of Germany
}

\begin{abstract}
Social behaviour and spawning of adult Blennius pavo kept in the laboratory are described. Eggs are deposited in batches on the walls of artificial spawning places (PVC pipes). One male guards and tends the eggs of different females in one spawning place. Larval hatching occurs in groups according to oviposition. Minimum incubation temperature is around $14-15^{\circ} \mathrm{C}$. Larval survival in 1-1 rearing jars is not related to larval total length but to density of larval stock. An experimental population of laboratory reared juvenile and adolescent $B$. pavo displays a male to female ratio of $1: 1.4$. Factors possibly influencing the sex ratio of this littoral fish are discussed in view of the situation in its natural environment.
\end{abstract}

\section{INTRODUCTION}

Blennius pavo is a small bottom living fish exhibiting a total length (TL) of about $120 \mathrm{~mm}$. It is common in the shallow littoral zone of the Mediterranean Sea. There, it abounds in the upper one meter of the water preferably among stands of green algae such as Ulva or Enteromorpha or under bolders and in crevices. The species is characterized by a distinct sexual dimorphism, described by Zander (1975) and Papaconstantinou (1979). The larger male (maximum length around $130 \mathrm{~mm}$ ) can be distinguished from the smaller female (maximum length around $110 \mathrm{~mm}$ ) by a typical hood or crest on its neurocranium and its brighter coloration especially during the season of reproductive activity. The mature male displays a light blue design in the face (white in Fig. 1) and the total body has a blueish-green hue with bright blue vertical lines and dots (Fishelson, 1963a). The female lacks the crest, and its coloration is dominated by brown patterns. In the nuptial phase, it too shows light blue vertical lines and dots on the lateral sides.

The male guards the eggs which are deposited by the females in crevices and holes of the littoral rocks. Breeding season in the Mediterranean is said to last from May until July (Eggert, 1932) or August (Fishelson, 1963a). While observations on feeding and reproductive behaviour of $B$. pavo are available (Fishelson, 1963a; Zander, 1975), little is known about larval survival and larval or juvenile development. Hence this study tries to close this gap in our knowledge on the biology of $B$. pavo, one of the very common fish in the littoral zone of the Mediterranean. 


\section{MATERIAL AND METHODS}

Juvenile Blennius pavo (TL: 50 to $75 \mathrm{~mm}$ ) were caught during July in Ulva and Enteromorpha stands at Fiascherino (La Spezia, Italy) using a hand net. 23 specimens, the sexes of which were not yet distinguishable by secondary sex characters, were transferred into a basin $(90 \times 90 \times 20 \mathrm{~cm})$ containing 1201 of seawater, connected to a circulated sea water system run at a salinity of roughly $34 \%$ at $15^{\circ} \mathrm{C}$. The fish were kept under natural daylight conditions and the fish tank was additonally illuminated by a fluorescent light in a 12:12 h light/dark rhythm in order to provide enough light for the growth of algae. The basin was provided with PVC-pipes about $15 \mathrm{~cm}$ long with different diameters $(20$ to $40 \mathrm{~mm}$ ) to serve as shelter and spawning places. The fish were fed commercial fish feeds (TetraMin) and occasionally Mytilus edulis meat was offered, which was taken readily.

After 9 months in captivity the specimens displayed clear sexual dimorphism and after 12 more months spawning could be observed. As soon as a male B. pavo had its PVC-pipe lined with spawn, pipe and fish were moved to a separate basin. The male continued taking care of the eggs. Hatching larvae were counted. 30 to 50 individuals were anesthetized (MS 222) and their total length determined.

Table 1. Blennius pavo. Data on rearing conditions ( \pm standard deviation of mean)

\begin{tabular}{|c|c|c|c|c|}
\hline Type & $\begin{array}{c}\text { Temperature } \\
\left({ }^{\circ} \mathrm{C}\right)\end{array}$ & $\begin{array}{l}\text { Salinity } \\
(\% o)\end{array}$ & $\begin{array}{c}\text { Iight } \\
\text { conditions }\end{array}$ & $\begin{array}{l}\text { Water } \\
\text { volume (l) }\end{array}$ \\
\hline Larvae & $21^{\circ} \pm 2.7$ & $30-32$ & $\begin{array}{l}\text { natural } \\
\text { daylight }\end{array}$ & 1 \\
\hline $\begin{array}{l}\text { Juveniles } \\
\text { in group }\end{array}$ & $21^{\circ} \pm 0.7$ & $34 \pm 1.2$ & LD $12: 12$ & $\begin{array}{l}200 \\
\text { recirculated }\end{array}$ \\
\hline $\begin{array}{l}\text { Iuveniles } \\
\text { in isolation }\end{array}$ & $21^{\circ} \pm 1.8$ & $34 \pm 1.8$ & LD $12: 12$ & $\begin{array}{l}100 \\
\text { recirculated }\end{array}$ \\
\hline Adults & $15^{\circ} \pm 0.8$ & $34 \pm 1.5$ & $\begin{array}{l}\text { natural } \\
\text { daylight } \\
\text { LD } 12: 12\end{array}$ & $\begin{array}{l}120 \\
\text { recirculated }\end{array}$ \\
\hline
\end{tabular}

Larval rearing was conducted in 1-1 aerated glass jars, the outer walls of which were lined with dark cardboard paper to prevent the larvae from bumping against the walls. Larvae were fed with Brachionus and, once large enough, with Artemia nauplii. Water was exchanged every second day (water quality parameters see Table 1). Benthic stages were transferred to a large rearing basin $(90 \times 150 \times 20 \mathrm{~cm})$ in a recirculated sea water system. Rearing temperature was $21^{\circ} \mathrm{C}$ at about $34 \% \mathrm{~S}$. Once the population was 6 months old a group of 80 individuals was removed and transferred to individual rearing chambers $5 \times 5 \mathrm{~cm}$ in dimensions in a recirculated sea water system $\left(21^{\circ} \mathrm{C}, \mathrm{S}=34 \%\right.$ ). The experimental conditions for all experiments are depicted in Table 1 . The total length of the fish was measured every one to two months to the nearest $\mathrm{mm}$.

On this occasion the fish were sexed from their outer appearance according to whether or not the male crest (Eggert, 1932; Papaconstantinou, 1979) was present. 


\section{RESULTS}

\section{Observations on spawning behaviour}

As soon as the males showed secondary sex characteristics (hood and dark hue), they moved into one of the PVC-pipes which they kept as housing for the whole period of observation. The females continued roaming around in the basin. Although there were four mature males in a relatively limited area $\left(0.8 \mathrm{~m}^{2}\right)$, fighting between the males for breeding places or females was never observed. During the total period of observation (more than three years) all parental fish survived.

Without any noticeable external stimulus such as rise in temperature, alteration of illumination or salinity, females became gravid and started to spawn in the pipes inhabited by the males. Females spawned several times and with different males. Thus a single male fertilized and guarded eggs from different females. At times, all four males of the laboratory stock were guarding eggs. Eggs were deposited inside the pipes in a single layer and subsequent egg deposition occurred only at places free from previously spawned eggs. At times males "owned" two adjacent spawning places and females deposited eggs in two different nests.

\section{Care of eggs}

Males guarded the eggs throughout incubation. The males constantly performed undulating movements with their body, thus pumping water through the pipes. At the same time, the bottom of the pipes was brushed or wiped with the pectoral fins in order to remove feces or accumulated debris. Larvae hatched dead were brushed out. In addition, the males performed frequent revolutions along their longitudinal body axis. During this procedure, the males probably applied mucus to the eggs from glandular areas on the dorsal parts of their lateral sides. During the care of eggs, these parts
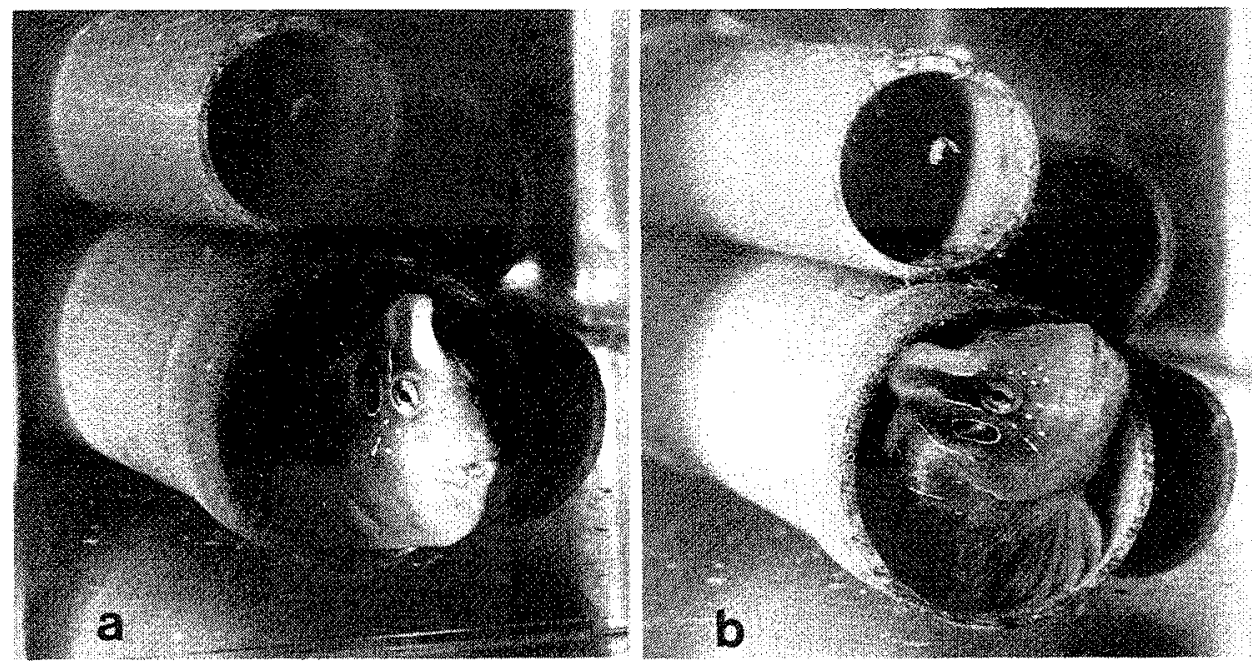

Fig. 1. Blennius pavo. Male (a) guarding nest with eggs, and (b) after a longitudinal revolution 
appeared conspicuously covered with grey thick mucus. Figure 1 shows a male $B$, pavo (a) during the care of eggs and (b) after the completion of a revolution.

Whenever males were taking care of two spawnings they alternated between these two in fairly regular intervals. Observations over a period of 20 days revealed no significant differences ( $t$-test; $\mathrm{P}<0.01$ ) between the times allotted to the care of two different spawns. After a total observation period of $480 \mathrm{~min}$ the male had spent $246 \mathrm{~min}$ in Nest A and 234 min in Nest B. Even over long periods, the care was fairly equally divided. The fish never "forgot" that it had two nests, and always left one nest to take care of the second. Only after all the larvae in one pipe had hatched did the male stop alternating between the two nests.

\section{Hatching and larval survival}

\section{Hatching}

Incubation time varied from 8 days at $23.7^{\circ} \mathrm{C}$ to 16 days at $18-19^{\circ} \mathrm{C}, 20$ to 21 days at $16^{\circ} \mathrm{C}$ to 41 days at $15^{\circ} \mathrm{C} .15^{\circ} \mathrm{C}$ seemed to be the lowest possible incubation temperature since frequently not all the eggs hatched at this temperature. As in other fish (Alderdice \& Velsen, 1971), larvae hatched primarily during the night and larval size varied with rearing temperature and origin. Although only data from different spawnings are available and size variation in larvae hatching in one nest are considerable (Figs. 2, 3), mean size (TL) of newly hatched larvae was found to be clearly temperature dependent. At $15^{\circ} \mathrm{C}$ TL was $4.88 \pm 0.11 \mathrm{~mm}$; at $18-19^{\circ} \mathrm{C}$ larval total length fell to $4.85 \pm 0.13$, and at $23.7^{\circ} \mathrm{C}$ larvae measured $4.65 \pm 0.16 \mathrm{~mm}$ only. The first larvae of one spawning batch were small; then, during maximum hatching, larval size was largest finally dropping at the end of the hatching period. Minimum total length for newly hatched larvae was $4.24 \mathrm{~mm}\left(\right.$ at $23.7^{\circ} \mathrm{C}$ ) while the largest individuals measured $5.2 \mathrm{~mm}$ (at $15^{\circ} \mathrm{C}$ ).

Due to the different sizes of the hatching larvae and due to the hatching peaks, the number of egg deposits guarded by one male could be determined. Thus Figures 2 and 3 reveal that we were dealing with three $\left(23.7^{\circ} \mathrm{C}\right)$ and $4\left(15^{\circ}, 18-19^{\circ} \mathrm{C}\right)$ egg clusters per male. The different sizes of the larvae per brood and rearing temperature indicate the existence of at least three different mothers for the egg clusters of Figure 2. For the egg clusters at $15^{\circ} \mathrm{C}$ (Fig. 3), at least two different females can be determined as mother individuals.

Larvae from the different egg depositions could be best separated at $15^{\circ} \mathrm{C}$ (Fig. 3). Four batches of hatching larvae could be recognized with distinct hatching peaks. Larval size increased from the beginning of hatching towards the peak and decreased versus the end. At higher temperatures, separation of larvae hatching from different batches became difficult, since peaks were obscured due to shortening of the hatching period. Yet on the basis of larval length, even at $23.7^{\circ} \mathrm{C}$, three batches could be distinguished.

At temperatures below $15^{\circ} \mathrm{C}$ hatching of larvae from one nest was spread over a long period of more than 40 days. No typical peaks for maximum hatching could be distinguished and larval hatching was distributed more or less irregularly over the whole period of hatching.

\section{Survival}

Newly hatched larvae swam actively and had well developed pectoral fins. The mouth functioned and one day old larvae took Brachionus readily. After 4 days at $21{ }^{\circ} \mathrm{C}$, 
Artemia nauplii were devoured. It took 18 days at $21^{\circ} \mathrm{C}$ for the first larvae of one batch to develope far enough to take to the bottom (Fig. 4),

Although generally more than $80 \%$ of the larvae initiated feeding, larval survival

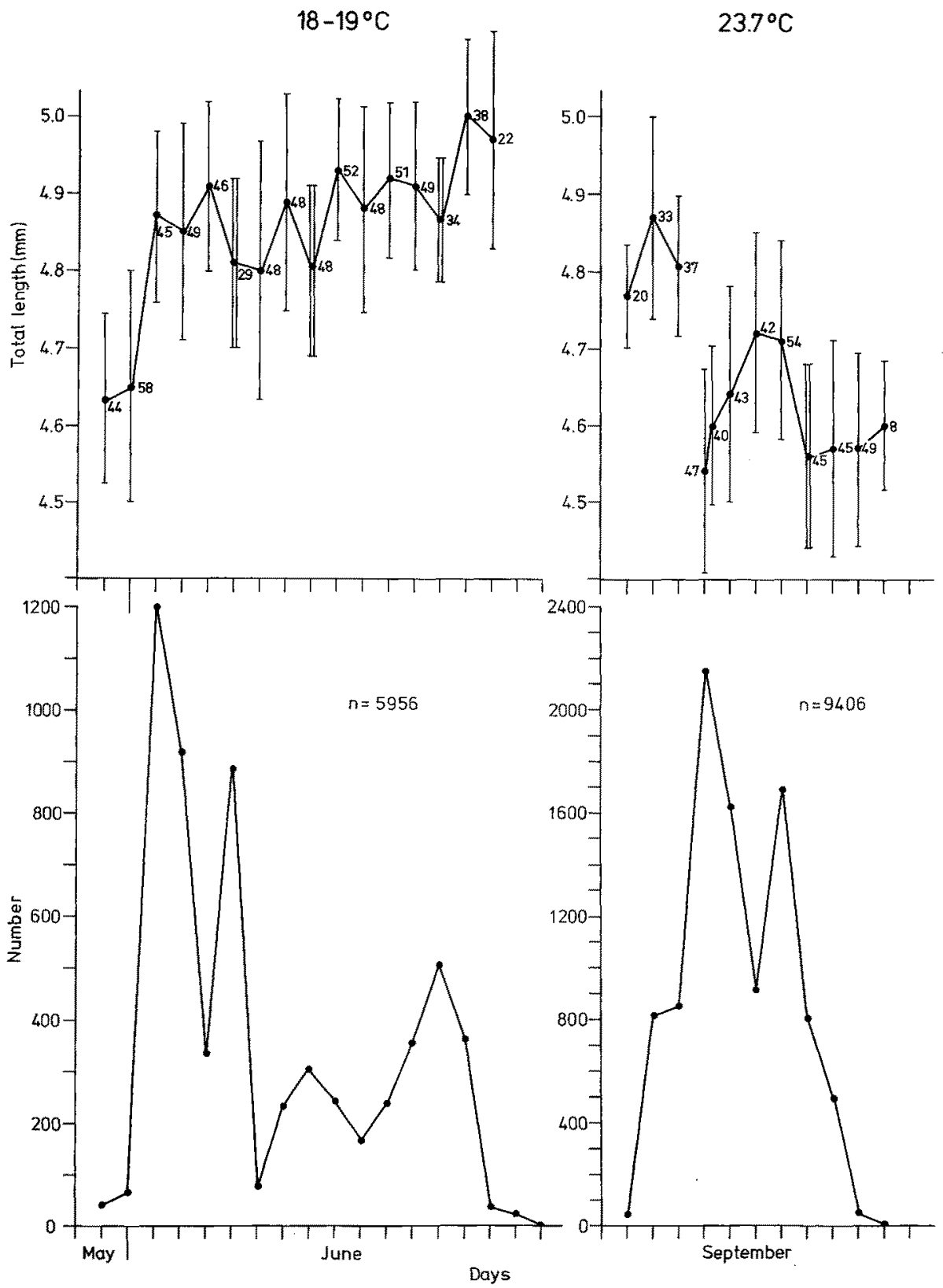

Fig. 2. Blennius pavo. Hatching distribution and total length of newly hatched larvae from two different spawnings at different incubation temperatures. Double bars: adjoining hatching groups 
(larvae which successfully assumed benthic living) varied from 3.3 to $58 \%$ (Fig. 5). Survival was not dependent on total length of newly hatched larvae but on larval density in the rearing jars, although food (Brachionus) was given ad libitum. Increase in

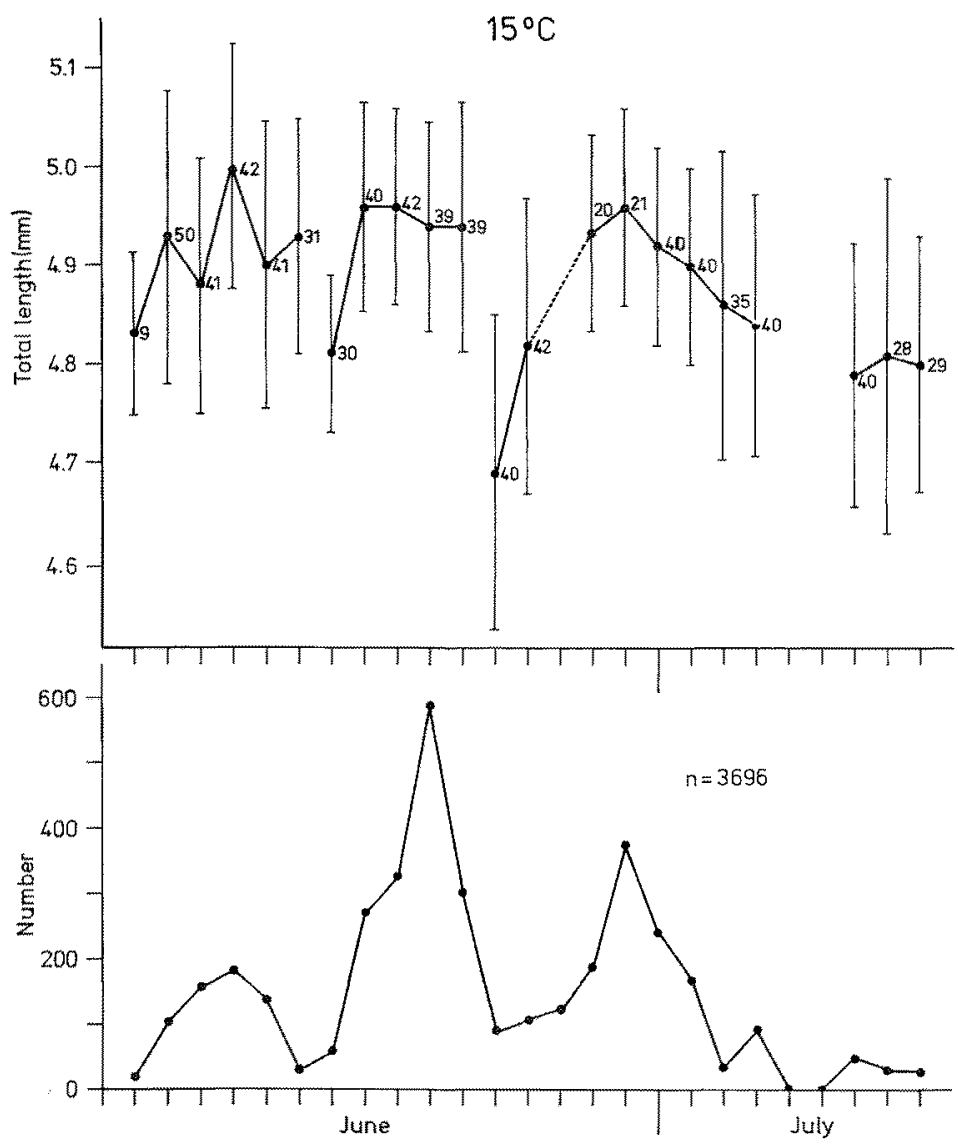

Fig. 3. Blennius pavo. Hatching distribution and total length of newly hatched larvae from one spawning. Broken line: no data

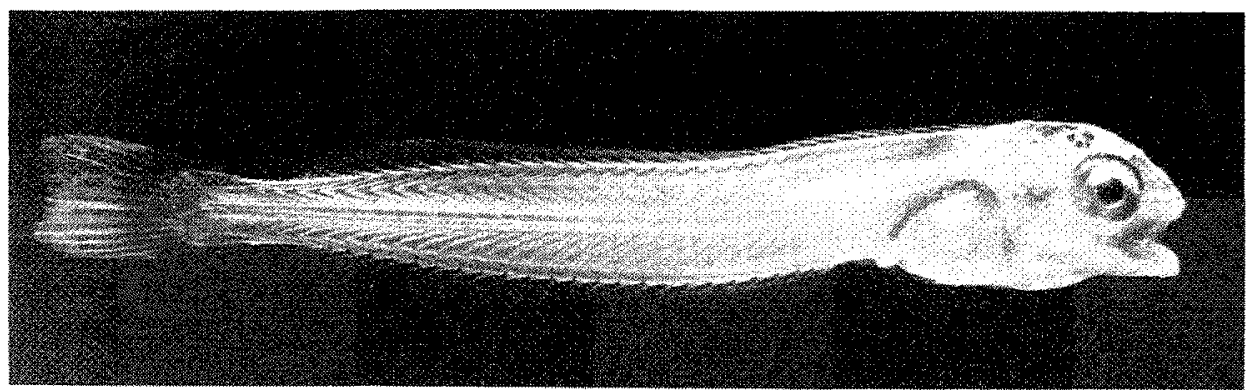

Fig. 4. Blennius pavo. Late planktonic larvae ready to assume benthic mode of living. TL: $13.1 \mathrm{~mm}$ 
numbers of surviving larvae with declining density followed a hyperbola $\mathrm{r}_{52}=-0.55$ ), approaching a maximum survival of $50 \%$ at a density of about 15 larvae per litre. At high stocking densities, mortality of larvae was expecially high during the transition from the larval phase to the benthic stage. While late pelagic larvae did not show any external signs of mutilation (Fig. 4), the developing territorial behaviour of the young bottom stages was accompanied by biting, and young bottom stages showed severe biting marks on fins and tails, which were frequently fatal.

\section{Group rearing of juveniles}

After transfer from the 1-1 jars to larger rearing tanks, the fishes grew considerably, and at an age of 6 months (Fig. 6 [6]) at $21^{\circ} \mathrm{C}$ the mean total length of the population was $34.4 \pm 7.2 \mathrm{~mm}(\mathrm{n}=128)$. Larger individuals (starting at $\mathrm{TL} 35 \mathrm{~mm}$ ) were already recognizeable as males by their developing hoods. As the population grew older, the number of clearly recognizeable male and female individuals increased (Fig. 6A), reaching a male to female ratio of $1: 2.3$ at an age of 13 months. At this stage, about $24 \%$ of the population were male, $55 \%$ were female and $21 \%$ were either too small to be

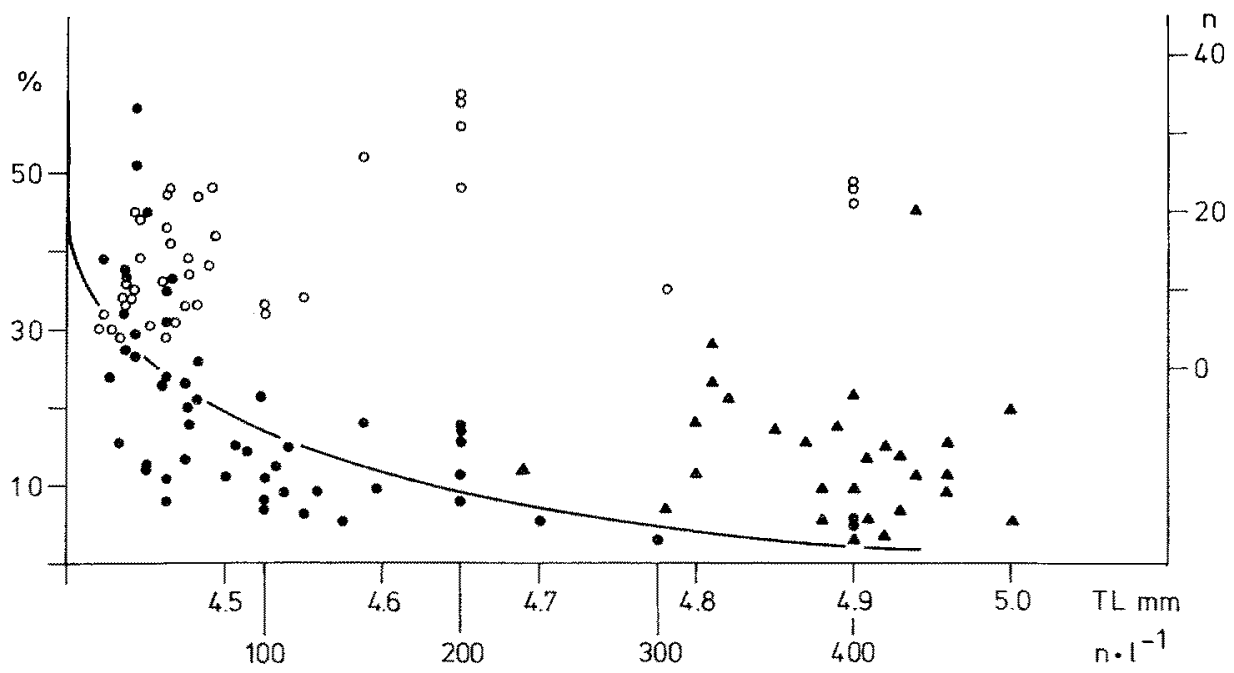

Fig. 5. Blennius pavo, Larval survival in 1-1 rearing jars in relation to total length ( 4 ) and stocking density (*). Left ordinate: survival (\%); right ordinate: absolute numbers of survivors (o) in relation to stocking density

sexed by external characters or kept an in-between position as shown in Figure $7 \mathrm{~b}$. The mean total length of the males was $50.0 \pm 7.1 \mathrm{~mm}$ and the females measured only $43.0 \pm$ $5.6 \mathrm{~mm}$. Both males and females then showed an approximated normal distribution. With the population growing, the male group developed a distinct two-peak distribution (Fig. $6[16,18]$ ), while the females continued to display a normal distribution. The larger size group (more than $65 \mathrm{~mm}$ TL) consisted almost exclusively of males except for one female and one non-sexable individual. 


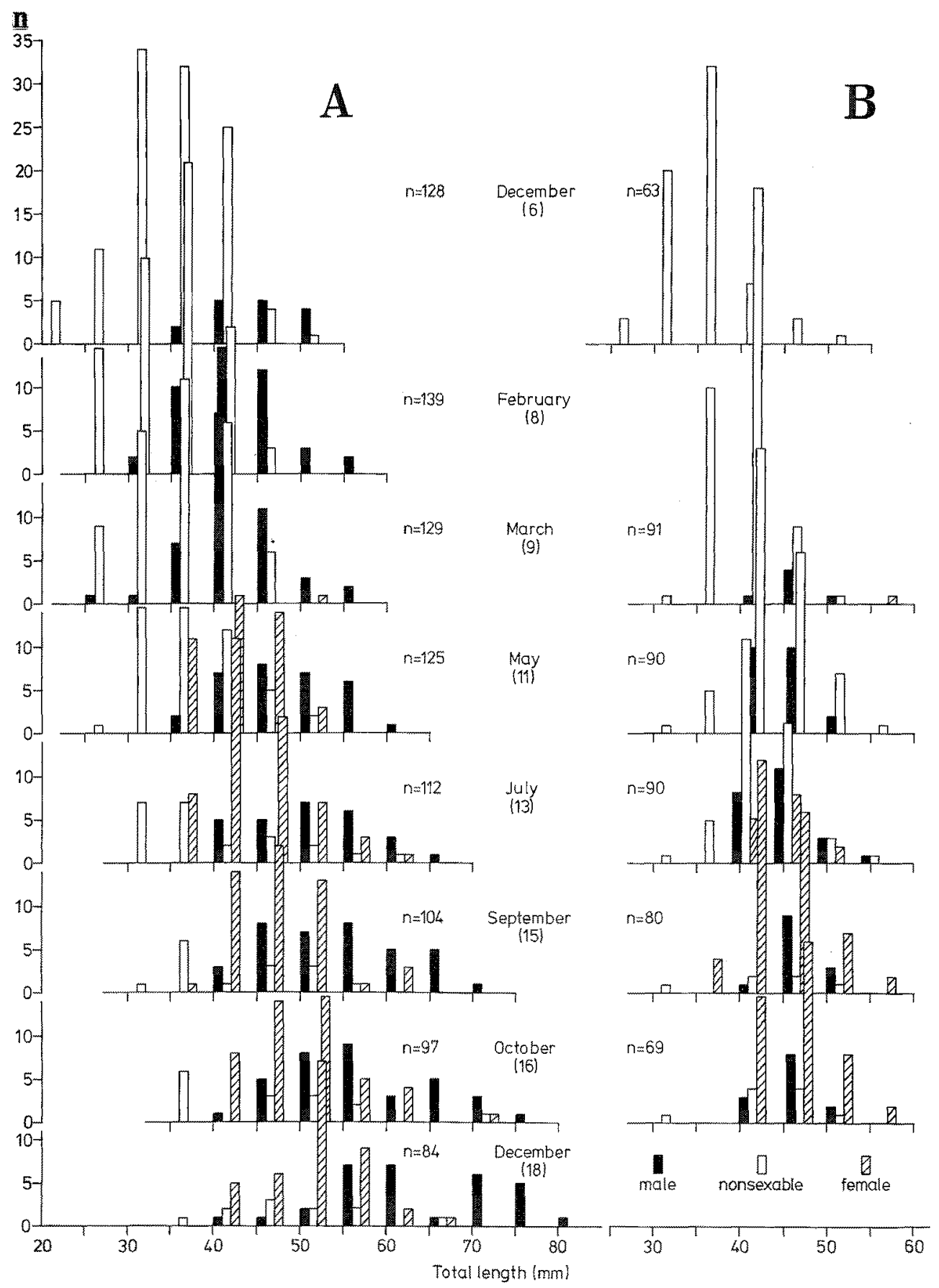

Fig. 6. Blennius pavo. Growth of juveniles reared $(\mathrm{A})$ in groups (stocking density $=84-128$ ) and $(\mathrm{B})$ in isolation in a closed sea water system $\left(21^{\circ} \mathrm{C} ; \mathrm{S}=34 \times 10^{-3}\right)$ (Figures in parentheses indicate age of animals in months) 
During the last 4 months of the experiment, the sex ratio remained around 1:1.4; with the males comprising about $36 \%$, the females 48 to $50 \%$ and the non-sexables between 13 and $14 \%$ of the total population.

\section{Rearing of juveniles in isolation}

Development and growth of the individuals held in isolation initially proceeded according to the pattern already observed in the former group. Males first became noticeable at a total length of $40 \mathrm{~mm}$; both sexes' total length displayed about normal distribution. At an age of 13 months the females' mean total length was $44.0 \pm 3.4 \mathrm{~mm}$; similarly males

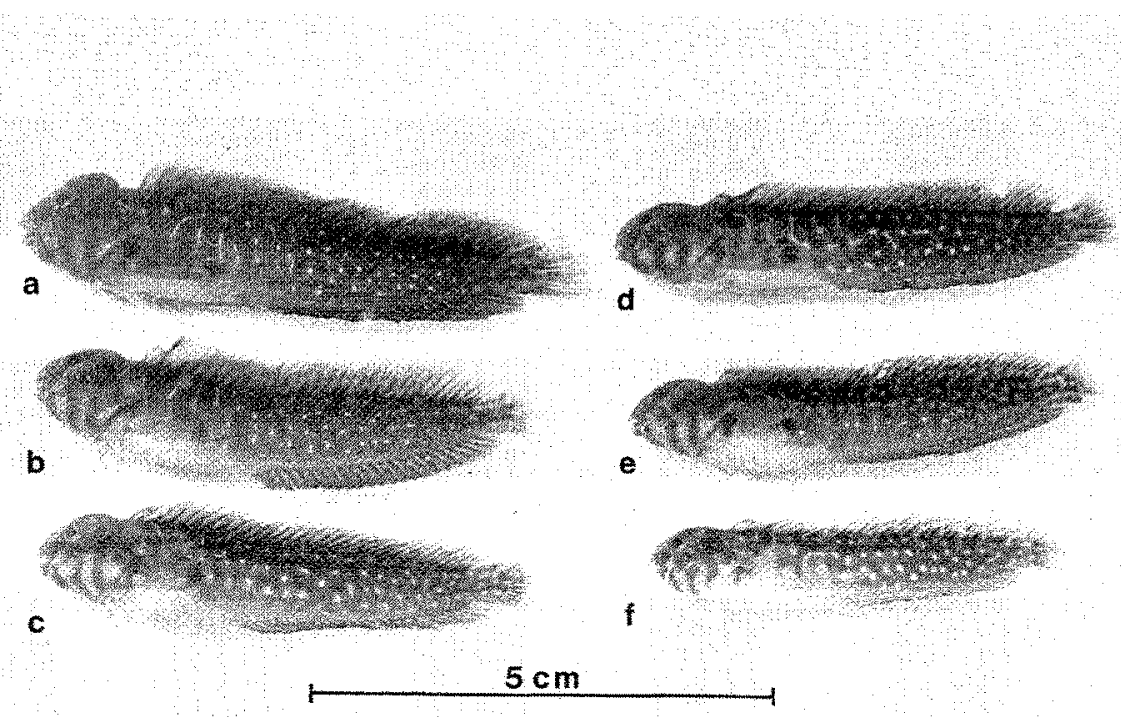

Fig. 7. Blennius pavo. Juveniles reared in the laboratory. $a$, $c$ : male; $d-f$ : female; $b$ : non sexable

measured $44.3 \pm 4.1 \mathrm{~mm}$ (Fig. 6B). After three more months (16) sizes of males and females were still identical (TL: $44.6 \mathrm{~mm}$ ); besides, the animals did not show any length increment. Male to female ratio in the isolated specimens was $1: 3.5$, and $14.5 \%$ of the animals were non-sexables.

\section{DISCUSSION}

The observations on colour patterns and behaviour made during the study of Blennius pavo are in general agreement with those reported by Fishelson (1963a) for in situ observations. Yet the aggressive behaviour of adult males during the reproductive season as described by Eggert (1932) and. Fishelson (1963a) has never been observed by us. Although the population density was fairly high (23 mature individuals, 10 males, in a basin of $80 \times 150 \mathrm{~cm}$ ) compared to a naturally occurring density of $10 \mathrm{fish} \cdot \mathrm{m}^{-2}$ 
(Fishelson, 1963a), and despite the fact that there were always several males displaying nuptial coloration, no fighting for nesting places or territories, except for occasional threatening, was observed.

In fact it seemed as if no established territories existed at all, since males guarding eggs occurred side by side, their nests only some $10 \mathrm{~cm}$ apart. It was also not so that the largest male (TL: $123 \mathrm{~mm}$ ) dominated all other males to the extent that they were entirely prevented from participating in the breeding activities, as observed by Fishelson (1963a). At times, up to 4 different males were observed guarding eggs, and the nest always consisted of at least three egg clusters which, determined on the basis of the different larval lengths at hatching, had been deposited by up to three different females (Fig. 2). One reason for the apparent absence of aggressive behaviour might have been the fact that the basin was provided with a surplus of shelters for the males in the group. Thus, since the males were not vagrant, once each male had moved into its own shelter no fighting opportunity developed.

In the experiment, the reproductive season proved quite long. The first spawning could be observed by the end of March, and the last spawning occurred in December, later than in the field where the spawning season is said to last until August (Fishelson, 1963a).

Rearing temperature was $15^{\circ} \mathrm{C}$ throughout, and since the fish were exposed to natural daylight, but not natural temperature conditions, the light regime must have been the stimulus for oviposition, as found for Blennius pholis by Shackley \& King (1977). Some of the males, however, appeared to be always in reproductive mood, since different males displayed nuptial coloration throughout the year. The extension of the spawning period might have been due to the relatively low water temperature of $15^{\circ} \mathrm{C}$, which is probably below the optimum rearing temperature for the species, but it provides the investigator with egg and larval material almost continuously throughout the year.

At all temperatures, larval length at hatching was greater than described by Fishelson (1963b) who reported newly hatched larvae of $B$. pavo 3.0-3.2 mm long, or Cipria (1936) who measured $4.2 \mathrm{~mm}$ (TL). As observed in other fish species (Forrester \& Alderdice, 1966), the duration of hatching decreased with increasing incubation temperature, lasting from 4 to 5 days at $23.7^{\circ} \mathrm{C}$ to 8 days at $15^{\circ} \mathrm{C}$ for a cluster of eggs from one single deposition.

The incubation period increased considerably with falling incubation temperature, $15^{\circ} \mathrm{C}$ being probably the lowest possible temperature for successful incubation as followed from the irregular distribution of hatching below this temperature and from the fact that at and below $15^{\circ} \mathrm{C}$ not all the eggs hatched, and the male fish left the nest with developed but non-hatching embryos still in their egg cases.

The larval length distribution followed that observed in other marine fishes. With increasing incubation temperature, larval length decreased (Forrester \& Alderdice, 1966; Alderdice \& Velsen, 1971; Ryland et al., 1975). Among the larvae hatching from one single oviposition, length varied with time of hatching. The early hatched larvae were small, increasing in size once approaching the median hatching time and decreasing in length towards the end of the hatching period. This phenomenon is commonly observed in the length distribution of newly hatched larvae and has been described in detail by Alderdice \& Velsen (1971) for Pacific herring. 


\section{Larval survival}

Larval survival varied from more than $50 \%$ to $3 \%$, values which are commonly obtained when rearing pelagic marine fish larvae under similar conditions (Engraulis mordax, Lasker et al., 1970; Anchoa mitchilli, Achirus lineatus, Saksena \& Houde, 1972). The phenomenon that larval survival was inversely related to stocking density has also been documented by Houde $(1975,1977)$ when rearing Archosaurus rhomboidalis, Anchoa mitchilli and Achirus lineatus larva in 1-1 containers. In A. mitchilli larvae this effect occurred at relatively low-level densities between 1 and 32 individuals per litre, and in $A$. rhomoidales optimum survival was achieved at stocking densities of 8 individuals per litre. As in Houde's experiments, effects of initial stocking density on larval survival of B. pavo were not well defined but existent, and optimum stocking density of 15 larvae per litre are in good agreement with the findings of other authors working with various marine fish species (Okamoto, 1969; Olesen \& Minck, 1983; Lasker et. al., 1970; Theilacker \& McMaster, 1971; Saksena \& Houde, 1972). In older larvae, the bottom stages of $B$. pavo might have developed some sort of territorial behaviour which might have caused casualties through biting; this is of particular interest while it would occur only in demersal fish species with pelagic larvae, since the relative stocking density of the larvae had gone up while the larvae were changing from the threedimensional space of the total water volume to a two-dimensional distribution in the bottom of the rearing jars. Houde (1975) postulated a competitive interaction among larvae, which leads to reduced growth and survival. This phenomenon could not be well defined in pelagic species such as in anchovies, but in demersal forms the above mentioned behaviour might contribute to increased mortality during and after the transition stage.

\section{Development of juveniles}

One of the observed phenomena during the development of the juveniles was the early occurrence of "crested males" in the experiments. At a total length of $40 \mathrm{~mm}$, a size at which they were supposed to be still juvenile, Blennius pavo males developed a typical crest on the neurocranium, a sign for initiation of maturation. In situ, the hoods develop much later and Eggert (1932) described a male specimen of $68 \mathrm{~mm}$ that had not yet developed his hood although practically mature. Our own observation in the field confirm that crested males are usually at least $70 \mathrm{~mm}$ in length. Differentiation between male and female on the basis of crest formation, especially in small individuals, is difficult, since females, too, bear traces of a hood (Eggert, 1932). Figure 7 demonstrates that external sex discrimination in adolescent $B$. pavo is somewhat critical. Specimen $a$ can be determined clearly as male, specimen $c$ is considered male too. Specimen $b$ is non-sexable and specimens $d-g$ are considered females.

The question whether the observed unequal sex ratio is an artifact due to failure in sexing because of the late or non-appearance of the crest (see Eggert, 1932), or it is an effect of social control of maturation as described for Xiphophorus variatus (Yamagishi et al., 1974) which delays the maturation of the males, or whether it is social control of sex, as described by Fishelson (1970) for the protogynous fish Anthias squamipinnis and the cleaner wrass Labroides dimidiatus (Robertson, 1972), is at this stage of the investigations impossible to answer; in particular since, for the time being, detailed histological 
information is wanting. There is, however, an indication for the probability of the existence of social sex control in $B$. pavo since Heymer (1980) reported sex reversal in a female $B$. basiliscus, a species closely related to $B$. pavo, after the dominant male of the group had died. Exact information on the subject will be provided after the evaluation of histological sections of different stages of development of $B$. pavo, the results of which are going to be published in due course.

Comparing the development of the two populations, the isolated and the group reared one, we notice distinct differences between the two groups. The development of the group reared population is typical for population growth in fish with territorial behaviour or size hierarchy. The phenomenon that the difference in size between the smallest and the largest individual increased with size is known as growth depensation (Jones \& Thompson, 1980), and is well known to aquaculturists. Besides, it has been documented by Brown (1946) for brown trout Salmo trutta, by Allee et al. (1948) for the green sunfish Lepomis cyanellus, and Yamagishi et al. (1974) for Odontobutis obscurus reared in captivity. The phenomenon has also been observed in the field by Doherty (1982) in the territorial damselfish Pomacentrus wardi. In the population of isolated $B$. pavo specimens, this phenomenon could not occur (Fig. 6). Yet the in situ situation will differ from the laboratory experiment in the sense that generally bottom stages and juveniles are not going to find habitats devoid of other B. pavo, but they will settle in areas with an existing $B$. pavo population and thus the newcomers for the time being will have to remain females if socially controlled sex determination exists in the species under consideration.

The question as to how far the experimentally obtained results are applicable to the field situation cannot be answered yet, since no information is available on sex ratio and size distribution of $B$. pavo in natural populations. It might be conceivable, however, that in situ sex ratio, too, is determined by one of the factors mentioned above. Growth depensation and the number of nesting holes available might be further factors influencing the mechanism of sex determination in B. pavo populations.

Acknowledgement. I am indebted to G. Fürstenberg for taking care of the experimental fish and expert technical assistance.

\section{LITERATURE CITED}

Alderdice, D. F. \& Velsen, F. P. J., 1971. Some effects of salinity and temperature on early development of Pacific herring (Clupea pallasi). - J. Fish. Res. Bd Can. 28, 1545-1562.

Allee, W. C., Greenberg, B., Rosenthal, G. M. \& Frank, P., 1948. Some effects of social organization on growth in the green sunfish, Lepomis cyanellus. - J. exp. Zool. 108, 1-20.

Brown, M. E, 1946. The growth of brown trout (salmo trutta L.). I. Factors influencing the growth of trout fry. - J. exp. Biol. 22, 118-129.

Cipria, A., 1936. Uova, stadi embrionali e postembrionali nei Blennidi, 1. Blennius pavo Risso - 2. Blennius inaequalis C. V. - Memorie R. Com. talassogr. ital. 231, 3-7.

Doherty, P. J., 1982. Some effects of density on the juveniles of two species of tropical, territorial damselfishes. - J. exp. mar. Biol. Ecol. 65, 249-261.

Eggert, B., 1932. Zur Kenntnis der Biologie, der sekundären Geschlechtsmerkmale und des Eies von Blennius pavo Risso. - Z. Morph. Okol. Tiere 24,682-703.

Fishelson, L., 1963a. Observations on littoral fishes of Israel I. Behaviour of Blennius pavo Risso (Teleostei, Blenniidae). - Israel J. Zool. 12, 67-80.

Fishelson, L., 1963b. Observations on littoral fishes of Israel II. Larval development and metamorphosis of Blennius pavo Risso (Teleostei, Blenniidae). - Israel J. Zool. 12, 81-91. 
Fishelson, L., 1970. Protogynous sex reversal in the fish Anthias squamipinnis (Teleostei, Anthiidae) regulated by the presence or absence of a male fish. - Nature, Lond. 227, 90.

Forrester, C. R. \& Alderdice, D. F., 1966. Effects of salinity and temperature on embryonic development of the Pacific cod (Gadus macrocephalus). - J. Fish. Res. Bd Can. 23, 319-340.

Heymer, A, 1980. Schleimfisch: Weibchen wird Männchen. - Umschau 80, 178-179.

Houde, E. D., 1975. Effects of stocking density and food density on survival, growth and yield of laboratory-reared larvae of sea bream Archosargus rhomboidales (L.) (Sparidae). - J. Fish. Biol. $7,115-127$.

Houde, E. D., 1977. Food concentration and stocking density effects on survival and growth of laboratory-reared larvae of Bay Anchovy Anchoa mitchilli and lined sole Achirus lineatus. Mar. Biol, 43, 333-341.

Jones, G. P. \& Thompson, S. M., 1980. Social inhibition of maturation in females of the temperate wrasse Pseudolabrus celidotus and a comparison with the blennioid Tripterygion varium. - Mar. Biol. 59, 247-256.

Lasker, R., Feder, H. M., Theilacker, G. H. \& May, R. C., 1970. Feeding, growth, and survival of Engraulis mordax larvae reared in the laboratory. - Mar. Biol. 5, 345-353.

Okamoto, R., 1969. Rearing of red sea bream larva. - Bull. Jap. Soc. scient. Fish. 35, 562-566.

Olesen, J. O. \& Minck, F, 1983. A technical solution to the mass-culturing of larval turbot. Aquacult. Engng 2, 1-12.

Papaconstantinou, C. A., 1979. The secondary sex characteristics of the genus Blennius of the Mediterranean Sea (Pisces: Blenniidae). - Rapp. P. v. Réun. Commn int. Explor. scient. Mer Méditerr. 25/26, 265-287.

Robertson, D. R., 1972. Social control of sex reversal in a coral reef fish. - Science, N. Y. 177, $1007-1009$.

Ryland, J. S., Nichols, J. \& Sykes, A. M., 1975. Effect of temperature on the embryonic development of the plaice, Pleuronectes platessa L. (Teleostei). - J. exp. mar. Biol. Ecol. 18, 121-137.

Saksena, V. P, \& Houde, E. D., 1972. Effect of food level on the growth and survival of laboratoryreared larvae of bay anchovy (Anchoa mitchilli Valenciennes) and scaled sardine (Harengula pensacolae Goode and Bean). - J. exp. mar. Biol. Ecol. 8, 249-258.

Shackley, S. E. \& King, P. E., 1977. The reproductive cycle and its control, frequency of spawning and fecundity in Blennius pholis L. - J. exp. mar. Biol. Ecol. 30, 73-83.

Theilacker, G. H. \& McMaster, M. F., 1971. Mass culture of the rotifer Brachionus plicatilis and its evaluation as a food for larval anchovies. - Mar. Biol. 10, 183-188.

Yamagishi, H., Maruyama, T. \& Mashiko, K., 1974. Social relations in a small experimental population of Odontobutis obscurus (Temminck et Schlegel) as related to individual growth and food intake. - Oecologia 17, 187-202.

Zander, C. D., 1975. Secondary sex characteristics of blennioid fishes (Perciformes). - Pubbl. Staz. zool. Napoli 39 (Suppl.), 717-727. 